\title{
Multinationals and changing national business systems in Europe: towards the 'shareholder value' model?
}

\section{Phil Almond, Tony Edwards and Ian Clark}

\begin{abstract}
This article reviews recent development in employment relations in MNCs, within the context of the varied and changing business systems within Western Europe. Focusing on Germany, France, Sweden and the UK, we analyse both the effects of national corporate governance systems on MNCs, and the extent to which MNCs specifically, and globalisation more widely, have affected the nature of national business and employment systems. While elements of a move towards a more 'Anglo-Saxon', economically liberal model of corporate governance and employment relations can be detected in all four countries, this is far from complete. Cross-national differences in business systems within Europe therefore continue to exert effects upon MNCs.
\end{abstract}

\section{Introduction}

Last year, the review of multinational companies (MNCs) in this journal (Clark et al., 2002) explored the means by which industry-specific pressures were to some extent mediated by the effects of national business systems. Specifically, the means by which airlines and IT corporations dealt with crisis was seen to be affected by the socially constructed nature of capitalism within the countries in which such firms were based. Although there was some evidence of common international patterns in organisational strategy and structure within the two sectors, the concrete form of firm-level responses to severe competitive pressures was seen to differ, with notable effects on employment relations. This work expanded on the discussion in the previous year's review (Muller-

$\square$ Phil Almond is Research Fellow and Ian Clark is Principal Lecturer at De Montfort University. Tony Edwards is Lecturer in International HRM at King's College, London. Correspondence should be addressed to Phil Almond, Department of HRM, De Montfort University, The Gateway, Leicester LE1 9BH, UK: palmond@dmu.ac.uk 
Camen et al., 2001), which concentrated on the relationships between home and host country influences on the employment relations practices of MNCs.

Developments in 2002 suggest that a concentration on reactions to crisis remains a fruitful line of enquiry. A range of linked factors have contributed to negative sentiment with regard to economies worldwide. First, the continuing fallout from the events of 11 September 2001, combined with continued geo-political uncertainty; second, the continuation of low levels of economic growth across major world economies; third, the extremely poor performance of stock markets across the world.

The third factor, while partly explicable by poor economic performance and the uncertainties of the 'war on terror', has been exacerbated by other factors. Stock market uncertainty, in part a result of the bursting of the speculative bubble of the dot.com boom, has been intensified due to a more general loss of trust in the financial results of major corporations. The emblematic representation of this remains the collapse of Enron in December 2001. However, this situation hardly improved in 2002: of the five largest bankruptcies in the USA in 2002, four (Worldcom, Conseco, Global Crossing and Adelphia Communications) faced major accounting scandals. The implication of auditors and analysts in several of these affairs has provoked a more general crisis of confidence in the US model of corporate governance.

Such scandals, and their inevitable effects on the perceived reliability of corporate earnings figures, have provoked a crisis that is far from being confined to Americanowned firms. Given this crisis in financial markets, and particularly with the concept of 'shareholder value', it would seem appropriate, in reviewing recent developments in employment relations within MNCs in Europe, to extend our previous focus on national business systems in order to take account of the mutual pressures operating between MNCs and national systems of corporate governance.

Thus, in examining developments in the systems by which corporations are governed within European countries, and their effects on MNCs operating within those countries, this review will touch on a number of issues. First, it will explore the extent to which the neo-liberal shareholder value ideology is now embedded in European business systems, and the conflicts this may bring about within national systems of industrial relations. MNCs, by their very nature, have a particularly important role within such developments, as will be seen below. This allows us to re-visit questions raised in our previous review articles (Muller-Camen et al., 2001; Clark et al., 2002) about the extent to which business and employment systems remain distinctive to specific countries, and how this may impact on the choices made by MNCs with regard to the management of human resources. Although detailed answers to the questions raised here are beyond the scope of an annual review, it is our belief that some light may be shed on the subject by looking at a number of recent critical instances affecting the operations of MNCs in European countries. In order to permit some degree of depth to the analysis, the review will concentrate primarily on significant developments, or prominent cases, within four European Union (EU) countries, selected for their apparent differences in the nature of corporate governance and industrial relations. These are: the United Kingdom, chosen for its approximation to the familiar classification of a 'liberal market economy', particularly the 'arms-length' relationship between owners and managers (Hall and Soskice, 2001); Germany, as the most significant representative of the 'coordinated market economy' and for the distinctive role of banks as major influences on firms (Hall and Soskice, 2001); Sweden, also a 'coordinated market economy', but one in which investment foundations rather than banks are major shareholders in firms; and France, where co-ordination mechanisms, including industrial relations, are generally seen as being most heavily dependent upon the activities of the State.

The review will be organised as follows. First, we briefly introduce the concept of shareholder value, including the likely characteristics of a system governed by such notions, and the role of MNCs in any move towards such a system. Second, we highlight the importance of industrial relations within a discussion on MNCs and corporate governance within Europe. We then examine developments in the four countries in turn, before drawing a number of tentative conclusions. 


\section{Shareholder value in Europe?}

The 'shareholder value' model of capitalism (Lazonick and O'Sullivan, 2000) emphasizes the primacy of the interests of stock holders over other stakeholders within the enterprise. A detailed explanation of the processes by which the nature of capitalism (particularly in liberal market economies) has moved towards such a model is beyond the scope of this article (see O'Sullivan, 2000). The implication, however, is that increasingly liquid capital markets, dominated by institutional investors, have led to the establishment of a 'market for corporate control'. Within this system, the managers of publicly-quoted corporations are constrained to maximise the net present value of the assets under their control. This is argued, particularly in the USA, to have had two main effects, which are closely related. Firstly, it is sometimes argued the managerial revolution of the early twentieth century ( $c f$ Chandler, 1977) has been superseded by a move towards a modus operandi which concentrates on maximising short-term returns ( $c f$ Useem, 1993). Hence, the time-scales of corporate decisions have been radically reduced as firms have moved away from retaining profits for reinvestment in the business, to a model under which assets are 'rationalised' and profits distributed among shareholders. The proportion of profits made by American firms which is distributed to shareholders in the form of dividends and share buy-backs rose from an average of just under 50 per cent in the 1960s and 1970s to around 70 per cent in the 1980s and 1990s (O'Sullivan, 2000). This is referred to by O'Sullivan as the 'downsize and distribute' model of contemporary capitalism. Second, and crucially, the notion of a market for corporate control can only be seen as realistic to the extent to which different management teams can be said to compete for the right to manage the corporation, based on their respective claims to be able to maximise shareholder value. The main concrete representation of this is the hostile takeover.

For our purposes, several questions arise at this point. First, to what extent are the corporate governance systems of employers in European Union countries moving in the direction of such a model? Second, what role do MNCs play in national debates over corporate governance, and conversely, what effects do existing national systems of governance exert on such firms? Finally, what is the role of industrial relations systems within such debates?

These questions will be considered more thoroughly with regard to the specific countries which are analysed in more detail, but it is perhaps useful to make a number of preliminary remarks at this point. It is clear that, taken as a single entity, the European Union does not yet operate under the assumptions of 'shareholder value', at least not to the extent of the USA. Using the classification of Hall and Soskice (2001), of the 15 current member states, only the United Kingdom and Ireland can genuinely be said to fit within the classification of 'liberal market economies', which, by virtue of their outsider model of corporate governance, are most likely to tend towards the contemporary American model. Of the remaining member states, a number fit within the 'coordinated market economy' classification (e.g. Germany, Austria, Netherlands, Sweden), while a further group, more difficult to classify, are sometimes (perhaps not entirely convincingly) classified as 'state market economies', or as following a 'Latin' model.

One clear indication of the nature of a national corporate governance system is the pattern of ownership of firms. In 'insider' systems, the owners of large firms (often banks) having a long-term relationship with the firm, and close links with managers. In 'outsider' systems such as that of the USA, large firms are mainly owned by private or institutional portfolio investors with little active interest in the day to day management of the firm. Given the liquidity of the capital market, they also have relatively little attachment to the long-term fortunes of the business. Evidently, the latter type of system tends rather more towards the shareholder value model. However, it is necessary to go beyond this rather narrow definition of what 'corporate governance' consists of. In essence, the question for those with an interest in industrial and employment relations outcomes is wider, and can be simplified to the extent to which 
the national business system leads firms towards a 'shareholder' model (the liberal market economies), or towards some form of 'stakeholder' model.

It is at this point that it becomes evident that industrial relations institutions are of central importance. The ability of employees, as individuals or through collective means, to affect management decisions is central to any serious discussion on national differences within capitalism, as well as to changes within national systems. There are good reasons for expecting there to be linkages between corporate governance systems on the one hand and systems of industrial relations on the other. This is a central part of Hall and Soskice's notion of 'institutional complementarities'; 'nations with a particular type of co-ordination in one sphere of the economy', they argue, 'should tend to develop complementary practices in other spheres as well' (2001: 18).

In this vein, Gospel and Pendleton (2003) argue that the structure of ownership and the preferences and demands of owners have a number of implications for managerial decision-making. In particular, they argue that the dominance of shareholder interests characteristic of outsider systems discourages institutions of employee voice; owners in these systems perceive unions and works councils to present barriers to actions, such as swift reductions in headcount in response to a downturn in demand, that deliver greater returns to themselves. Accordingly, where there is a shift towards a 'shareholder value' orientation in countries previously characterised by the insider model we might expect this to lead to challenges to established systems of employee representation.

Hall and Soskice (2001: 18-19) present evidence indicating that outsider systems have weaker institutions of employment protection than do insider systems. Among OECD countries, a strong correlation exists between an index of the strength of employment protection on the one hand and the extent to which the stock market is highly developed on the other; countries such as the UK and USA which have a high 'stock market capitalisation' - a key feature of outsider systems-have relatively weak systems of employment protection. ${ }^{1}$ In contrast, insider systems such as Germany and France have a low stock market capitalisation and strong systems of employment protection.

Further evidence which is consistent with a link between the systems of corporate governance and industrial relations can be drawn from a study commissioned by the European Industrial Relations Observatory (EIRO, 2002a) into the nature of industrial restructuring across the European Union. In countries with stable insider systems restructuring in response to changes in product market conditions tends to be relatively modest, measured and negotiated. For example, in Denmark, where the system of 'personal stakeholder capitalism' is based on the prevalence of family ownership and employee rights to elect members of the company board, restructuring has been limited in scope and has presented only modest adjustment costs to employees. In contrast, in Britain, the outsider model creates strong pressures on firms to deliver shareholder value, and the minimalist framework of employee rights means that restructuring takes place primarily on terms set by shareholders rather than employees.

In other EU countries, however, the situation is more complex. Some insider systems appear to be evolving towards the outsider model, and patterns of restructuring are becoming more marked. This is the case, for example, in the Netherlands where a market for corporate control is growing and institutional investors are becoming more influential. Accordingly, many large firms, particularly Dutch and Anglo-Dutch multinationals such as Phillips, Shell and Corus, have been active in restructuring their operations. The gradual shift towards the outsider system of corporate governance in

\footnotetext{
${ }^{1}$ Hall and Soskice's (2001: 19) employment protection index 'is a composite measure of the relative stringency of legislation or collective agreements dealing with hiring and firing, the level of restraint embedded in collective dismissal rules, and the extent of firm-level employment protection'. Their measure of how highly developed is the stock market is based on 'the market value of listed domestic companies as a percentage of GDP'.
} 
the Netherlands has presented challenges to the system of social concertation in the industrial relations arena. However, these IR institutions are relatively resilient. While some restructuring that has had adverse consequences for employees has occurred, in other cases employee representatives have been able to block proposed changes. A key instance of this is the case of Corus, where the Dutch supervisory board vetoed the sale of the metals business to Pechiney of France, forcing management into making cuts elsewhere in the firm.

\section{European governance systems and MNCs}

As can be seen from the above discussion, the nature of corporate control and of employee rights and influence varies considerably within the EU. It is also evident that all the systems are facing pressures which, to a greater or lesser extent, are in the direction of a system based less on a stakeholder model and more on a shareholder model. Within this, MNCs play a specific role. This operates in two main ways, affecting, respectively, domestically and foreign-owned MNCs.

First, MNCs based within EU countries compete primarily against other MNCs, whether markets can truly be said to be 'global' or not. As large firms from countries with 'insider' systems increasingly follow globalising strategies, their relationship with their home country alters in a number of ways. First, the shareholder base may be internationalised, with shares increasingly being quoted abroad, particularly on Wall Street. This has the potential to expose such firms to the shareholder value ideology under which American managers are constrained to operate. For instance, Hoescht had its shares traded in ten countries (prior to its merger with Rhone Poulenc), and VW and Bayer both have 13 stock market listings, although the effects of this development on the nature of governance are limited by the concentration of voting rights in Germany in general and among insiders in particular (Lane, 2001). More widely, firms which see themselves as operating globally may move towards a global logic, potentially at odds with the embedded logic of capitalism in their home base. This is arguably the case, for example with regard to firms such as Danone and Michelin in France announcing redundancies in spite of both the corporation and the relevant business units being profitable (see below).

Moreover, the logic of operating within a national system, which firms might have seen as beneficial (or at least tolerable) when operating primarily in domestic markets, is likely to be reduced when competing on a more international basis. The most direct incarnation of this is reducing employment in the home country in favour of less regulated foreign economies, where this is feasible. Equally, this potential, whether openly expressed or not, may lead MNCs to lobby successfully for reductions in employee influence and less constraining labour laws.

Second, foreign-owned MNCs operating within EU countries have a complex role within debates on corporate governance, broadly defined. Although such firms are evidently less directly affected by the nature of domestic relations between ownership and management, the amount of incoming FDI is likely to correlate positively with the extent to which there is a market for corporate control facilitating takeovers of host country firms.

Equally, existing research has demonstrated that foreign-owned MNCs have the potential to play a distinctive role within national employment systems. The extent to which this is the case depends on the relationship between country of origin (or home country) effects, host country effects, pressures for the international integration of operations, and the potential such firms have to direct investment toward more 'favourable' employment systems (cf Cooke and Noble, 1998; Traxler and Woitech, 2000). In other words, although conformance with the host country system is by no means excluded (Turner et al., 1997), foreign firms operating within a given country may export the cognitive and normative assumptions of managers in the home country, such that the domestic 'best way' of operations is effectively exported ( $c f$ Ferner, 2000; Ferner et al., forthcoming). These 'foreign' practices may well be seen as 
innovative in the host country (Muller-Camen, 1998), or even as a model to be imitated (EEF, 2001).

In other cases, home country practices may be regarded as 'deviant' when exported into foreign environments, in the sense that they break with host-country norms. In France, for example, cases include the legal difficulties faced by IBM in attempting to apply its performance management system in France (EIRO, 2002b), and the difficulties faced by McDonald's in contesting the collective rights of its employees (EIRO, 2002c). It has been argued that the firms' attachment to home country practice is likely to be stronger when 'home' industrial relations systems are largely firm-based; hence American and Japanese firms might be more likely to export employment relations and HR practices than firms from more actively regulated economies (Ferner, 2003). However, this cannot be taken for granted, as witnessed by the decisions of German car manufacturers to establish global works councils (EIRO, 2002d). Further, the subset of MNCs that approach the archetype of the 'global firm' may well attempt to adopt relatively similar HR practices across their different operations, both in order to achieve standardisation of product or service, and in order to minimise transaction costs within the process of the management of human resources through economies of scale.

Within such discussions, it is important to bear in mind the obvious point that foreign MNCs are significant employers, both in themselves and by virtue of local supply chains. Because of this, nations and regions within trade blocs such as the EU are likely to compete for FDI. The availability of skills at the lowest available unit cost, combined with limits on the ability of the state or employees to constrain management decision making, are likely to be valued by employers. It is often concluded that this is one of the main reasons for the relatively high proportion of European FDI to be found in its two liberal market economies, the UK and Ireland. Such a reading is simplistic, as a number of factors are likely to be significant, including access to markets, fiscal regulations, language, privatisation, the deregulation of markets and the existence of a developed market for corporate control, to name but a few. It remains the case, however, that existing and potential foreign direct investors retain substantial lobbying power in the area of employment relations. At the very least, such arguments are frequently used in order to justify government decisions to restrict employee rights.

In summary, both domestically and foreign-owned MNCs have a key role to play within both academic and policy discussions on the relations between the owners, managers and workers of firms. Such issues are now explored in more detail by examining recent developments in France, the UK, Germany and Sweden.

\section{France}

The French economy has, historically, been heavily affected by the active role of the state. This extends to economic planning, the role of nationalised industries, a postwar settlement that largely sought to exclude organised labour and hence continued to rely heavily on codified labour law (Howell, 1992), and, significantly, in the depth of networks between the top managers of firms and senior civil servants (Hall, 1986).

The frequent characterisation of France as a 'state market economy', however, is outdated. This is reflected not only in a wave of privatisations, which continued under the Left government of 1997-2002, but also in a wave of (not entirely successful) attempts to decentralise industrial relations from the 1970s onwards (cf Howell, 1992).

Certain trends towards a shareholder value ideology are visible within French firms. For example, the trend has been towards a higher proportion of profits being distributed to shareholders, rather than reinvested in the firm; this increased dramatically from 23 per cent to 41 per cent between 1994 and 2000 (EIRO, 2002a). Additionally, senior managers are increasingly paid according to the performance of shares (Le Monde, 2003), another hallmark of a system based on shareholder value (O'Sullivan, 2000). In spite of such changes, however, any victory for the 'shareholder value' ide- 
ology is only partial. Despite a number of high profile corporate take-overs, particularly in the financial sector, most of these were 'friendly' in nature, and a genuine market for corporate control cannot be said to exist (EIRO, 2002a). One might also add that the crisis and scandal surrounding Vivendi, where the former CEO's personal strategy of expansion through acquisition, unchecked by shareholders, eventually ran into crisis following the collapse of the dot.com boom, highlight a number of contradictions in the French system. Specifically, there are clear contradictions between a French firm pursuing an acquisitive strategy based on the liberal market model, and the structure of corporate governance in France-particularly the relative lack of shareholder rights to monitor senior management. The near-collapse of this company is likely, at least in the short-term, to provide a domestic credibility barrier to the shareholder value ideology within France.

With regard to industrial relations, trade unions are generally weak at workplace level. In spite of recent developments brought about by the necessity to negotiate working time reductions under the Aubry Laws (see below), firm-level collective bargaining is still limited in its effectiveness in determining the pay and conditions of employees. Equally, while works councils possess rights of consultation in the event of major changes within the enterprise, the effectiveness of these is generally limited to obtaining improved redundancy settlements. However, it remains the case that where such rights are ignored by firms, trade unions do have recourse to legal remedies, as was seen, for example, in the case of Marks \& Spencer's decision to close down its French operations (Muller-Camen et al., 2001).

Tensions between the French employment system and the nature of contemporary 'globalisation' have been highlighted by a number of prominent recent cases, primarily affecting major French-owned MNCs which have shown increased interest in maximising short-run shareholder value in order to attract capital from global institutional investors.

Perhaps the emblematic case was that of Michelin, which in October 1999 simultaneously announced a 17 per cent increase in profits, and 7,500 redundancies. This decision, taken in order to maximise shareholder value, so enraged public and political opinion to the extent that new legal provisions were eventually passed, requiring firms to begin negotiations on introducing a 35 hour week before any announcement of a redundancy plan. This is now generally referred to as the 'Michelin amendment' to the 'Social Modernisation Law' (EIRO, 2001a, see also below).

A second prominent case was that of Danone, which in January 2001 announced the closure of profitable biscuit production plants across Europe, in order to forestall future plans for divestment of the division by shareholders. It is notable that this decision was made in spite of a 14 per cent increase in divisional profits the previous year. However, margins remained lower than either other Danone divisions or those of major competitors. As has been argued elsewhere (EIRO, 2001a), this would seem to represent the 'industrial strategy' of corporate management, based on relatively longterm perspectives of product markets, being superseded by a 'financial strategy'. This development could easily be related to the fact that approximately 60 per cent of Danone shares were owned by institutional investors, of which almost half were British or American. It is worth noting that the controversy arising from this decision was unabated by the company's commitment to a redundancy plan adhering closely to 'best practice', in line with the firm's self-image as a 'socially responsible employer' (EIRO, 2001b).

From the negative public and political reaction to these and similar recent announcements, one can safely conclude that economic redundancies, particularly in profitable firms, remain particularly controversial in France (Muller-Camen et al., 2001). This is reflected by debates surrounding the 'Social Modernisation Law' passed by the Left Government in December 2001.

One of the aims of this law was to protect employment by squaring the circle between the corporate strategies of downsizing and restructuring within firms with exposure to international markets, and the national job creation strategy as represented by the Aubry Law reducing the maximum working week to 35 hours. The so-called 
'Michelin amendment' fitted within this argument, as did the requirement for firms to reduce 'structural overtime' before announcing redundancies, as well as proposing the redeployment of employees to jobs requiring equivalent skills requirements. Works councils were also given extended consultation powers in the event of redundancies.

The argument that there was significant public pressure to go further than this is supported by the passing in the National Assembly of a Communist Party amendment which would have restricted the scope for redundancy to a much greater extent. Redundancy would only be allowed in the case of economic difficulties, technological changes or requirements for re-organisation, if these were-in the view of the courts-necessary to ensure the survival of the company. This amendment was eventually rejected by the Constitutional Council (EIRO, 2002e), causing considerable embarrassment to the left-wing coalition government. However, the fact that this amendment was passed by parliament in the first instance does indicate the extent to which the nature of contemporary globalisation, and the strategies which MNCs claim to have to pursue in order to achieve success, are at odds not only with the existing system of industrial relations, but also with widely-held views on the legitimacy of such modes of corporate restructuring among the public.

Such societal understandings limit the room for manoeuvre available even to the right-wing government elected in June 2002. Although the current government has suspended several elements of the social modernisation law, and rejects the notion that redundancies can be prevented by legal means, it does refer fairly consistently to the need for social dialogue and finding better means of 'readjustment'. One method employed is the creation of a 'redundancy supremo' ('Monsieur licensiements'), charged with finding ways of dealing with the problems of economic adjustment (EIRO, 2002f).

Such moves are unlikely to prevent profitable French and foreign-owned MNCs from announcing redundancies. However, governments of the Right in France have to date been constrained, at least in rhetoric, to support social partnership built on existing institutions-rather than to argue in favour of more neo-liberal interpretations of 'deregulation'. Equally, micro-level economic adjustment remains a national political issue. In spite of changes in the ownership structure and modus operandi of French MNCs, a full-blown conversion to an 'Anglo-Saxon' understanding of corporate governance therefore appears unlikely to occur, at least in the short term.

\section{United Kingdom}

The British business and employment system remains distinctive within the broader framework of European regulation, with important consequences for choices made by MNCs. In the UK the 'outsider' model of investment, combined with a liberal framework of employment regulation, provides for a pattern of corporate governance and restructuring that is primarily determined by shareholders at the expense of employees. Together this model and associated framework of regulation lead to the assertion that MNCs reduce employment in the UK in favour of lower labour cost economies outside the EU. To test this assertion it is necessary to examine the attitudes, activities and intentions of MNCs in relation to two issues that may erode embedded features of the British business and industrial relations system. First, the impact of information and consultation committees on closure and location decisions made by MNCs, and secondly, the effect of British (self) exclusion from the Euro on investment decisions by MNCs. By reviewing these issues against recent decisions and against recently announced attitudes and intentions it is possible to shed further light on the role of MNCs in debates over corporate governance broadly defined and, conversely, to assess the impact that national business systems exert on MNCs.

\section{Redundancy and closure decisions}

Redundancy and closure decisions, whether they are made by domestic firms or MNCs, are easier and more swiftly determined in the British business system than in 
many business systems of other EU nations. Witness, for instance, the determined opposition in France and Belgium-eventually pursued in the courts-to 'British style press announcements' of closure and subsequent redundancies by Marks and Spencer. Announcing job losses via the press is normal practice in the British business system; recent examples include closure or redundancy announcements made by British Telecom in plans to re-locate directory inquires to India and a similar announcement made by Prudential. A more extreme example followed Ryanair's acquisition of KLM's low-cost subsidiary Buzz. Ryanair has previously demonstrated its anti-union credentials by fighting off a recognition claim for pilots and cabin crew. On acquisition of Buzz it announced the intention to close many of the airlines' routes and offer some staff new contracts of employment whilst paying others only the statutory minimum redundancy payment. None of the latter was done on the basis of consultation with the unions recognised at Buzz (Guardian, 2003).

For the TUC and many trade unions the introduction into British law of Information and Consultation committees will significantly reduce the scope to announce redundancies prior to consultation, whether by domestic firms or MNCs. The Information and Consultation Directive (Barnard and Deakin, 2002) compels employers to establish a democratic and collective mechanism to consult with their workforce on substantial changes in terms and conditions of employment such as changes in work organisation, the sale of subsidiaries and redundancy. British workplaces employing more than 150 workers have to introduce such a mechanism by 2005. For trade unions this will go some way to improve existing provisions for consultation over redundancy by distinguishing between proposed redundancies as opposed to actual redundancies, thus moving this aspect of employment regulation in the direction of the stakeholder model more familiar in other EU nations. However, many employers argue this mechanism will merely add to an already over-regulated administrative burden, and yet little value to existing provisions. More to the point, Alan Johnson, the employment relations minister, has consistently argued that information and consultation committees will not constitute co-determination or joint decision making (Financial Times, 2003a), and will not therefore impair the shareholder or outsider model of corporate governance.

Examination of recent closure and redundancy decisions provides a mixed picture in respect of the footloose nature of MNCs in the UK. British Telecom, Prudential and Ryanair have announced redundancy decisions in accordance with this assertion, but other foreign-owned MNCs demonstrate another tendency. The decision by Massey Ferguson's American parent AGco to close the Coventry plant was announced in a similar way to the cases mentioned above, yet production is being switched to France where labour costs are broadly comparable. Similarly, the recent decision of Ford to cease car production at its Dagenham plant saw production switched to Germany. In both of these cases the UK's minimalist framework of employment protection clearly played a part in the rapidity of redundancy announcements-as it did in earlier cases such as those of Vauxhall (General Motors), Corus and BMW. However, the impact of MNC activity in these five cases demonstrates a wider pan-European pattern of rationalisation where FDI decisions are made within a matrix that trades off skills and labour costs and the ability of individual states to restrain management decision making (Cooke and Noble, 1998; Ifo Institute, 1997). Within this environment, Sterling's recent appreciation against the Euro has seriously weakened the competitiveness of the UK's manufacturing sector within and beyond the Euro zone. Thus, while the introduction of information and consultation committees may create more orderly regulation of closure and redundancy decisions, their effect is likely to be limited to formalising decisions made beyond the ambit of the regulatory framework in the British business system.

\section{Foreign Direct Investment decisions}

The growing significance of the trade-off between skills and labour costs and domestic regulation within a national business system is demonstrated by recent evidence on MNC Foreign Direct Investment (FDI). Whilst the UK's pro Euro group Britain in 
Europe and the main anti Euro group Business for Sterling have each published material suggesting that membership or non-membership of the Euro zone will attract or deter further FDI by MNCs (Layard et al., 2002; Huhne and Canning, 2002; Sterling for Britain, 2002a, 2002b), both camps say relatively little or nothing about the British business system, labour market and regulatory framework.

Recently published survey evidence provides some data on the issue of FDI by MNCs and the UK's labour market and its regulatory framework. A British Chambers of Commerce survey (2003) suggests that 68 per cent of British firms consider that Euro membership will lead to higher levels of regulation, with 34 per cent arguing that membership would have no effect on FDI whereas 43 per cent argued it would increase. More detailed evidence flows from a Financial Times survey of 40 foreign MNCs operating in the UK, 19 of these, including Siemens, Caterpillar and PeugeotCitroen stated that FDI would fall whereas 12 firms argued Britain's membership of the Euro will have no effect on FDI. The majority of these, including the US firm Cummins, argued this was the case because the majority of their UK output is exported beyond the Euro zone (Financial Times, 2003b). A response common across the spectrum suggested that FDI is more influenced by the productivity and the skills base of local labour and not the regulatory framework. A survey for the German-British Chamber of Industry and Commerce (Hoppe et al., 2003) of 387 German firms with 780 British subsidiaries produced more detailed results on the British labour market and its regulation. Only four per cent of parent companies and 11 per cent of subsidiaries stated that the UK's more minimalist framework of labour market regulation represented a primary reason for locating in the UK whereas 58 per cent of parent companies stated that the importance, size and proximity to the UK market was the most important reason behind FDI in the UK. However, 30 per cent of firms stated that there is a lack of skilled labour in the UK with 50 per cent of firms experiencing difficulty in recruiting labour, but only nine per cent of firms stated that UK labour market regulations posed difficulties for them. Moreover, only six per cent of firms suggested that differences between German and British labour market regulations constituted a reason for FDI. Finally, over 70 per cent of parents and subsidiaries stated that if the UK remained apart from the Euro zone this would have no effect on their investment plans.

Drawing all the points together we can make two broad and general conclusions on the mutual pressures between national business systems and MNCs with respect to the British business system. First, the UK is a short-termist financier driven economy with an embedded pattern of voluntary minimalist market driven relationships (Lane, 1995), epitomised by the industrial relations system. Thus, the ease with which closure and redundancy decisions are announced by and formulated on shareholder terms is embedded within this framework. The introduction of information and consultation committees may bring greater order and representation to these decisions but the regulations are likely to reflect the minimalist approach. Second, FDI by overseas MNCs is less likely to be directly influenced by the UK's minimalist labour market regulations whereas closure and redundancies therein might be. However, FDI, closure and relocation decisions are as likely to be influenced by product markets, productivity and skill levels. As many MNCs now consolidate and re-structure on a pan-European basis these latter factors are likely to be the primary variables with the UK's looser redundancy laws making the announcement and execution of decisions swifter than similar decisions in other EU nations.

\section{Germany}

In Germany there are some signs that the insider model of corporate governance has been eroded recently. One of the visible manifestations of this are the sharp rises in the remuneration of senior managers. In several large German firms there have been rapid rises: in seven companies the average rise for board members in the period 1996-1999 was more than 100 per cent. A lot of these rises took the form of stock 
options and share-related bonuses that are typical of Anglo-Saxon firms, amounting to very significant increases in remuneration at companies such as Deutsche Bank (EIRO, 2002a). A related development has been the establishment by many German firms of 'investor relations' departments, charged with the responsibility of courting potential and actual institutional investors. In the autumn of 2002 a new Transparency and Disclosure Law came into effect which obliges managers to make more information available to shareholders, apparently strengthening the trend towards greater attention being paid to outside owners. Moreover, the orientation of some large German companies appears to have become much more centred around the USA and UK. This is especially so in those firms that have been involved in major mergers and acquisitions in these countries, such as Daimler and Deutsche Bank, where the centre of gravity appears to have shifted markedly. The hostile take-over of Mannesmann by Vodafone in 2000 could thus be interpreted as emblematic of a move towards the outsider model in Germany.

However, Germany continues to follow an insider model in a number of important respects. One of the distinctive aspects of the German system of corporate governance is the extent to which the ownership of companies is highly concentrated. Among 'stock corporations' 35 per cent belong to only one owner and 72 per cent have one owner who accounts for more than half of the shares. The percentages are comparable for 'limited liability companies' (43 per cent and 69 per cent respectively) (EIRO, 2002a, figures relate to December 1999). Moreover, a remarkably high number of large companies are not quoted on the stock exchange. In 1998 only 71 of the largest 100 companies had the legal form of joint-stock corporations, and only 51 of these were actively traded on the stock exchange.

There are two further distinctive aspects of the German system of corporate ownership that stand out. First, the banks are key players, owning just over 13 per cent of the shares in all stock companies in 2000 (a slight increase on 1991). Their influence is greater than this would suggest, though, because they often cast the proxy votes of a range of small shareholders. Second, there is a well-developed system of crossshareholdings between companies-the biggest category of owners of stock companies is 'non-financial companies', basically other companies. For example, the insurance company Munchner Ruckversicherung owns 26 per cent of another insurance company Allianz, while Allianz in turn owns 25 per cent of Munchner Ruckversicherung. This pattern of cross-shareholdings gives rise to a system of interlocking directorates in which senior directors of one firm sit on the boards of others in which there is a cross-shareholding.

A number of barriers to hostile takeovers remain in place in Germany. These include: the ownership structure, particularly the cross-shareholdings and role of the banks; the role of the state both as shareholder in some large firms and as regulator; the system of co-determination, affording employees rights to consultation and protection of changes to pay and conditions; and the two-tier board structure. Some argue that these barriers are beginning to be eroded, particularly the role of the banks as many give up their role of 'guardians against hostile takeovers' (Höpner, 2001). Generally, though, they remain strong, and the recent takeover law (WpUG) actually strengthened management's abilities to take defensive actions against hostile takeover bids (EIRO, 2002a). The Vodafone acquisition of Mannesmann appears to have been an exception rather than the start of a new trend.

The system of insider corporate governance is consistent with a system of employee representation based on relatively strong employee rights. The well-known features of the 'dual' system of employee representation involving Works Councils at firm level and collective bargaining at sectoral level have been challenged recently, leading to talk of an 'erosion' of the German model (Hassel, 1999; 2001). However, in comparative context they remain distinctive.

The way in which some German MNCs restructured their operations in 2002 reflected the domestic context. The construction firm Holzman AG-which employs 23,000 people, half of whom work outside Germany-announced an emergency plan designed to fend off the threat of insolvency. This plan involved selling off parts 
of the business and closing down others. While such a move may appear to be reminiscent of Anglo-Saxon style restructuring in response to shareholder demands, this was not the case at Holzman. It was the refusal of the banks to extend further credit to a company they had supported for years that forced management's hand (EIRO, 2002g).

A similar story is evident at T-Systems, the company formed by Deutsche Telekom through merging its own telecoms and IT service division with a similar division bought from Daimler-Chrysler. In 2002 T-Systems announced that 6,500 of the firm's 43,000 employees would be made redundant in response to adverse market conditions (EIRO, 2002h). Sharp cuts have also been made by almost all of the American firms that dominate the IT sector, such as Hewlett-Packard, Sun Microsystems and Lucent Technologies. The cuts at T-Systems were primarily a response to huge losses both in this division and the parent company, with the banks and the government (as Deutsche Telekom's largest shareholder), forcing the hand of management. Once again, the pressures of shareholder value and a shift to an outsider system do not seem to be key factors in the changes.

The fall-out from the Mannesmann-Vodafone case illustrates a further element of the insider system, namely the resilience of the German system of employee representation. Following its success in the takeover battle, Vodafone sought to dispose of the automotive, machine tools and pipes divisions. The sale of these nontelecommunications parts of the firm followed assurances from Vodafone about the avoidance of job losses, and indeed the new owners of these operations were obliged to give job guarantees for specified periods. More generally, Vodafone, a non-union company in the UK, has reluctantly acknowledged a requirement to develop and implement codetermination in Germany.

Overall, then, while there is talk of a more shareholder-oriented system, the prevalence of the rhetoric of shareholder value appears to be more a tool that senior managers use to legitimise change (especially hikes in managerial pay) than a reflection of a wholesale shift towards the outsider model of corporate governance (Lane, 2000). Rather, a careful reading of the evidence points to only modest change: ownership remains concentrated and distinctive in form; a market for corporate control along Anglo-Saxon lines does not exist; and the system of employee representation leads most firms to negotiate major organisational changes.

\section{Sweden}

The Swedish system of corporate ownership has tended to be stable and tolerant of an industrial relations system which affords employees considerable voice within firms. However, as is the case in Germany, many developments indicate a shift to an outsider model. One such development has been the growing popularity of share and profit-related bonuses for senior managers, something which has been a key factor in the widening distribution of pay in many Swedish firms (Hayden and Edwards, 2001). There is also a fairly high proportion of mergers and acquisitions, at least among publicly quoted companies. Of the 325 publicly quoted firms for which there are data, 33 were taken over in 1999, 26 in 2000 and 22 in 2001. Moreover, many large Swedish companies are highly internationalised, reflecting the small domestic economy which led them to become multinational at a relatively early stage in their development. Companies such as Ericsson, Electrolux and SKF have more than 50 per cent of their assets, sales and employees outside Sweden. Others such as ABB and Astra have merged with foreign firms, significantly reducing their concentration in Sweden; while others such as Volvo have fallen under foreign ownership.

However, the insider model remains intact in a number of important respects. The most important type of company in Sweden in terms of employment is the joint stock company, covering 220,000 companies and 2 million employees. Of these, only the largest 450 or so are quoted on the Swedish stock exchange. Amongst those that are publicly quoted the Swedish system of corporate ownership exhibits an unusual 
feature, namely the distinction between A and B shares. In most big Swedish firms, there are a small number of wealthy families, sometimes acting through an investment foundation, which own a significant number of A shares. These carry 10, 100 or even 1,000 votes, while the B shares, which are openly traded on the stock market, carry only one. The biggest of these foundations is the Wallenberg empire, which has stakes in many big Swedish firms. These linkages between the foundations and firms have proven to be stable and close, representing a marked contrast with the fluid and distant relations between institutional investors and firms in the UK and USA.

The system of A and B shares acts as an obstacle to hostile takeovers since in many cases it is impossible for a potential bidder to acquire a significant proportion of the voting shares on the stock market. A further obstacle to hostile takeover is the need for any acquisition or merger to be approved by two-thirds of the votes at a company meeting, not simply more than 50 per cent. Thus not one of the mergers or acquisitions that took place between 1999 and 2001 could genuinely be described as hostile in nature.

These features of the Swedish economy do not insulate Swedish companies from the pressures to engage in radical restructuring. Some Swedish MNCs which operate in internationally competitive sectors have undergone fundamental changes in recent years. In 2002, Ericsson continued its large-scale restructuring. Following 6,000 redundancies in 2000 and 2001, there were a further 10,000 redundancies in 2002. These look set to be followed by a further 17,000 in 2003 , as the firm looks to bring its total worldwide employment down from 105,000 in 2000 to around 65,000. These cutbacks have come alongside wide-ranging changes to the nature of management style at Ericsson, with its HQ being relocated to London and the adoption of Anglo-Saxon style forms of variable pay for managerial staff and some form of performance-related pay across the company.

However, the restructuring at Ericsson also reflects the distinctiveness of the Swedish political economy. For instance, the system of A and B shares results in three large Swedish shareholders holding around three-quarters of the voting rights in the company. These shareholders, which are investment foundations with long-standing links with the company, were influential in shaping the direction of the company in the 1990s. Unlike many of Ericsson's Anglo-Saxon counterparts, the firm has not engaged in aggressive acquisitions, growing primarily through greenfield investments and collaborative joint ventures. The response to adverse product market conditions also reflects the influence of the Swedish industrial relations system. During 2001 the government commissioned the former L.O. trade union official Hans Karlsson to supervise the redundancy process at Ericsson. His report coincided with a further redundancy announcement at the company in April 2002, but nonetheless he declared himself on the whole happy with the measures that management had taken to support employees affected, including 12 months' salary for every worker and extensive help with job search. To a large extent the firm followed the model of dealing with restructuring used at Norkopping in 1999. This broad approach has been followed to a lesser extent outside Sweden, for instance in Spain, where the company has resorted to making compulsory redundancies having exhausted other avenues (EIRO, 2002i).

Overall, the restructuring in Ericsson does not appear to have been driven by demands from shareholders for greater value to be delivered to them; rather it seems to be driven by managers who are keen to stem losses at the group. It has opened up a source of tension between managers and shareholders, in fact, with managers proposing a fresh issue of $\mathrm{B}$ shares, with plans to tie this to a reduction in the voting power of A shares to a maximum of 10 votes per share.

A further illustration of the influence of the insider model over Swedish MNCs was the merger in the telecommunications sector between Telia of Sweden and Sonera of Finland. Unlike in many mergers in outsider models which are driven by shareholder pressures to strip out costs, the Telia-Sonera merger was agreed by the two governments, which were the two biggest shareholders in each of the firms. The merger was not based on cost savings derived from redundancies, and hence had the support of trade unions. As a representative of the Swedish unions put it: 'There is a tough com- 
petitive climate nowadays. In order to survive you have to be strong, or else you get swallowed by someone else. The unions are aware of this' (quoted in EIRO, 2002j).

In sum, there are only very limited moves towards shareholder value in most Swedish organisations. Where there are moves, this is mainly confined to highly internationalised companies like Ericsson, and even here they should not be exaggerated. In this respect, MNCs may be breaking their ties with the Swedish system, but they have not lost them and they are not setting a wider trend across Swedish firms.

\section{Conclusions}

The material reviewed suggests that, except in the traditionally liberal British context, the business systems examined here do not yet approximate to Hall and Soskice's classification of liberal market economies, and hence cannot be said to fit within a 'shareholder value' model of corporate governance. This is not altogether surprising. In most European countries, at least some of the institutional requirements for the full embrace of a shareholder value model - a largely privatised social security system, an extensive proportion of household investment being directly or indirectly invested on the stock exchange, weak and/or uncoordinated trade unions-are not yet present. Despite considerable pressures and tensions, neither patterns of corporate ownership and management, nor the institutions by which employers interact with their employees, can be said to have eroded significantly, at least in so far as the discussion is confined to formal systems.

This is not to deny that significant changes in national business systems have taken place, which have been strongly influenced by the Anglo-American shareholder value model and the contemporary nature of corporate globalisation. All three of the continental European countries examined in detail here, have, for example, seen changes in the wage structure for top executives and increases in the extent of takeover activity, which would, on the surface, appear to offer evidence of some moves towards an acceptance of elements of the shareholder value ideology. However, as we have seen, the latter developments in particular do not amount to the emergence of a genuine market for corporate control (probably the single most significant element of a shareholder value system), but are, instead, responses to the changing nature of product market competition.

With regard more specifically to industrial relations institutions, requirements for consultation have generally survived intact. However, the survey evidence reported in the British case raises the question as to the effectiveness of such institutions in having a genuine effect on corporate decision-making, as opposed to simply affecting the process by which redundancies are announced. Much more cross-national evidence is needed on this.

MNCs are significant actors in these debates. Both domestic and foreign-based MNCs have evidently played an important role in the questioning of existing national systems of corporate governance, and have tended to present pressures towards less co-ordinated, more 'outsider' based systems. However, not only does there remain a significant gap between continental European systems and the idealised notion of a shareholder value model, but significant intra-European differences also exist (for details on a greater number of countries, see EIRO, 2002a). As with earlier 'convergence' arguments, it is probably safer to talk of trends in a given direction, occurring at different speeds from different starting points, rather than to reach the fatalistic conclusion that some idealised form of a 'shareholder value' model will inevitably come to dominate patterns of co-ordination between owners, managers and employees across Europe.

\section{References}

Barnard, C. and S. Deakin (2002), 'Reinventing the European Corporation? Corporate Governance, Social Policy and the Single Market', Industrial Relations Journal, 33, 5, 484-499. 
British Chamber of Commerce (2003), Survey on Euro Membership (London, British Chambers of Commerce).

Chandler, A. (1977), The Visible Hand: The Managerial Revolution in American Business (Cambridge, Mass, Belknap Press).

Clark, I., T. Colling, P. Almond, P. Gunnigle, M. Morley, R. Peters and M. Portillo (2002), 'Multinationals in Europe 2001-2: Home Country, Host Country and Sector Effects in the Context of Crisis', Industrial Relations Journal, 33, 5, 446-464.

Cooke, W. and D. Noble (1998), 'Industrial Relations Systems and US Foreign Direct Investment Abroad', British Journal of Industrial Relations, 36, 4, 581-609.

EEF (2001), Catching Up With Uncle Sam (London, Engineering Employers' Federation).

EIRO (2001a), 'Danone Reignites Controversy Over Redundancies In Profitable Firms', France, October. www.eiro.eurofound.ie. FR0102133F.

EIRO (2001b), 'Globalisation Blamed For Redundancies at Danone and Marks \& Spencer', France, April. FR0104147F.

EIRO (2002a), 'Corporate Governance Systems and the Nature of Industrial Restructuring', Comparative Feature, October. TN0209101S.

EIRO (2002b), 'IBM Staff Assessment System Questioned', France, April. FR0204103N.

EIRO (2002c), 'Industrial Action Hits McDonald's Restaurants and Franchises', France, February. FR0202104F.

EIRO (2002d), 'DaimlerChrysler Establishes World Employment Committee', Germany, September. DE0209204N.

EIRO (2002e), 'Constitutional Council Rejects Key Point Of 'Social Modernisation' Law', France, January. FR0201102F.

EIRO (2002f), ' “Redundancy Supremo” Appointed', France, November. FR0211103N.

EIRO (2002g), 'Holzmann Construction Company Files for Bankruptcy Protection', Germany, April. DE0204204F.

EIRO (2002h), 'Restructuring at T-Systems Tests Unions' Ability to Cooperate', Germany, October. DE0210201N.

EIRO (2002i), 'Ericsson Announces 700 Redundancies', Spain, September. ES0209206N.

EIRO (2002j), 'Swedish Unions Welcome Telia-Sonera Merger', Sweden, March. SE0203106N.

Ferner, A. (2000), 'The Embeddedness of US Multinational Companies in the US Business System: Implications for HR/IR'. De Montfort University Business School Occasional Paper No. 61.

Ferner, A. (2003), 'Foreign Multinationals and Industrial Relations Innovation in Britain' in P. Edwards (ed.), Industrial Relations: Theory and Practice, $2^{\text {nd }}$ edn. (Oxford, Blackwell).

Ferner, A., P. Almond, I. Clark, T. Colling, T. Edwards, L. Holden and M. Muller-Camen (forthcoming) 'The Dynamics of Central Control and Subsidiary Autonomy in the Management of Human Resources: Case Study Evidence from US MNCs in the UK', Organisation Studies (in press).

Financial Times (2003a), 'Managers Still Rule Unions Told', 17 January, p. 3.

Financial Times (2003b), 'Industry Highlights the Pros and Cons of Euro Entry', 18 January, p. 3.

Gospel, H. and A. Pendleton (2003), 'Finance, Corporate Governance, and the Management of Labour: A Theoretical and Comparative Analysis', Unpublished paper.

Guardian (2003), ‘O'Leary Tells Buzz Unions: I'll Close You Down', 5 February, p. 23.

Hall, P. (1986), Governing the Economy: The Politics of State Intervention in Britain and France (Cambridge, Polity Press).

Hall, P. and D. Soskice (2001), Varieties of Capitalism: The Institutional Foundations of Comparative Advantage (Oxford, Oxford University Press).

Hassel, A. (1999), 'The Erosion of the German System of Industrial Relations', British Journal of Industrial Relations, 37, 3, 483-505.

Hassel, A. (2002), 'The Erosion Continues: Reply', British Journal of Industrial Relations, 40, 2, 309-317.

Hayden, A. and T. Edwards (2001), 'The Erosion of the Country of the Origin Effect: A Case Study of a Swedish Multinational Company', Relations Industrielles, 56, 1, 116-140.

Höpner, M. (2001), 'Corporate Governance in Transition: Ten Empirical Findings on Shareholder Value and Industrial Relations in Germany', MPIfG Discussion Paper 01/5.

Hoppe, U., F. McDonald, H. Tuselmann and I. Wivell (2003), Germany Invests: Trends and Views on Direct Investment by German Companies in the United Kingdom (London, Deutsch-Britische Industrie-und Handeskammer).

Howell, C. (1992), Regulating Labor: The State and Industrial Relations Reform in Post-War France (Princeton, Princeton University Press).

Huhne, C. and N. Canning (2002), Crystal Balls (London, Britain in Europe). 
Ifo Institute (1997), 'The EU Mechanical Engineering Industry: Monitoring the Evolution of Competitiveness' (Munich, Ifo).

Lane, C. (1995), Industry and Society in Europe: Stability and Change in Britain, Germany and France, E (Cheltenham, Edward Elgar).

Lane, C. (2000), 'Understanding the Globalization Strategies of German and British Multinational Companies: Is a 'Societal Effects' Approach Still Useful?', in M. Maurice and A. Sorge (eds), Embedding Organizations (Amsterdam, John Benjamins).

Lane, C. (2001), 'The Emergence of German Transnational Companies: A Theoretical Analysis and Empirical Study of the Globalization Process' in G. Morgan, P. Kristensen and R. Whitley (eds), The Multinational Firm: Organizing Across Institutional and National Divides (Oxford, Oxford University Press).

Layard, R., W. Buiter, C. Huhne, W. Hutton, P. Kenen and A. Turner (2002), Why Britain Should Join the Euro (London, Britain in Europe).

Lazonick, W. and M. O'Sullivan (2000), 'Maximising Shareholder Value: A New Ideology For Corporate Governance', Economy and Society, 29, 1, 13-35.

Le Monde (2003), 'Les grands patrons sont-ils trop payés?', 22 May. Accessed on-line at www.lemonde.fr.

Muller-Camen, M. (1998), 'Human Resource and Industrial Relations Practices of UK and US Multinationals in Germany', International Journal of Human Resource Management, 9, 4, 732-49.

Muller-Camen, M., P. Almond, P. Gunnigle, J. Quintanilla and A. Tempel (2001), 'Between Home and Host Country: Multinationals and Employment Relations in Europe', Industrial Relations Journal, 32, 5, 435-448.

O'Sullivan, M. (2000), Contests for Corporate Control: Corporate Governance and Economic Performance in the United States and Germany (Oxford, Oxford University Press).

Sterling for Britain (2002a), Single Currency Single State? (London, SfB).

Sterling for Britain (2002b), The Business Case Against Joining the Euro (London, SfB).

Traxler, F. and B. Woitech (2000), 'Transnational Investment and National Labour Market Regimes: A Case of 'Regime Shopping'?', European Journal of Industrial Relations, 6, 2, 141-160.

Turner, T., D. D'Art and P. Gunnigle (1997), 'US Multinationals: Changing The Framework of Irish Industrial Relations', Industrial Relations Journal, 28, 2, 92-102.

Useem, M. (1993), Executive Defense-Shareholder Power and Corporate Reorganisation (Cambridge, MA., Harvard University Press). 